-Slavica

Acta Baltico-Slavica, 45

Warszawa 2021
Citation: Ragauskaite, A. (2021). Language contact between Lithuanian and Polish in the historical anthroponymy of Kedainiai town of the seventeenth and eighteenth centuries. Acta Baltico-Slavica, 45, Article 2529. https://doi.org/10.11649/abs.2529

\author{
Alma Ragauskaité \\ Institute of the Lithuanian Language \\ Vilnius \\ alma.ragauskaite@lki.lt \\ https://orcid.org/0000-0001-5952-8027
}

\title{
Language Contact Between Lithuanian and Polish in the Historical Anthroponymy of Kèdainiai Town of the Seventeenth and Eighteenth Centuries
}

Research on the historical multi-ethnic anthroponymy of Kedainiai is in progress. Based on the analysis of entries made in register books of Kedainiai in the seventeenth and eighteenth centuries, it can be observed that surnames emerged in different ethnic groups of the local urban community (Lithuanian and Polish). ${ }^{1}$ Higher-ranking residents of Kedainiai already had hereditary personal names in the first half of the seventeenth century, and the middle and lower social classes of townspeople acquired them in the second half. A slower formation of surnames was the case only among the lowest classes of the Kedainiai community.

Register books of Kedainiai from the eighteenth century contain a record of all residents of the town with hereditary anthroponyms (Ragauskaite, 2008, pp. 35-36, 2017b, p. 66). The analysis of binary names of local residents recorded in Kedainiai

${ }^{1}$ For more information about the ethnic and religious composition of the population of Kedainiai in the seventeenth and eighteenth centuries, see e.g. Ragauskaite, 2016, pp. 47-49, 2017a, pp. 113-115, 2017b, pp. 54-56, 2018c, pp. 175-176; Šinkūnas, 1928, pp. 21-36; Tworek, 1966, pp. 193-194, 1969, p. 213; Žirgulis, 2002b, pp. 130-134. 
inventories from the seventeenth century revealed that 180 such anthroponyms were of Lithuanian origin. Out of these historical surnames, 106 forms were reconstructed; $6(5.4 \%)$ of them were ancient Lithuanian double-stemmed anthroponyms; 5 (4.5\%) - hypocoristics of double-stemmed personal names and their suffixal derivatives; 95 (90.1\%) originated from nicknames. The comparison between 106 reconstructed anthroponyms and modern Lithuanian surnames indicates that $63(60 \%)$ of them continue to function today. Some of the reconstructed surnames (24, i.e. $23 \%)$ have modern counterparts of the same origin but different formation. The remaining 19 (17\%) have no equivalents in present-day anthroponymy (Ragauskaite, 2018b, p. 67).

Historical records of Kedainiai town from the seventeenth century were used to extract 906 personal names (second components in the binary nomination model, Lithuanian and Polish) of local residents. The 906 analysed anthroponyms were classified into two groups: personal names with Lithuanian and Slavic patronymic suffixes, respectively, -aitis, -ènas, -(i)onis, -(i)ünas and -evič, -ovič, diminutive suffixes and Polish suffixes of the -sk- type, and personal names without such suffixes. The first group was much larger - 666 personal names (73.5\% of all anthroponyms); the second group counted 240 (26.5\%) anthroponyms (Ragauskaite, 2018a, p. 112). As evidenced, several ethnic groups of the urban community of Kedainiai were characterised by different patterns of the naming system, surname formation, origin and structure. This confirms the relevance of the study and the need to continue research on the historical anthroponymy of Kedainiai residents in the seventeenth and eighteenth centuries.

This article aims to discuss Lithuanian naming trends specific to residents of Kèdainiai in the seventeenth and eighteenth centuries, underlining characteristic cases of Polonisation of their personal names and the most significant factors that affected the recording of anthroponyms in town books.

The anthroponymic material for this study was mostly extracted from the seventeenth- and eighteenth-century town records. ${ }^{2}$ With a major part of Kedainiai town books from the seventeenth century lost in a fire, the early records are mostly missing (Žirgulis, 2002a, p. 24). The Office of the Chief Archivist of Lithuania holds 24 register books of Kèdainiai written in Latin and Polish. These books are among the most significant sources of historical anthroponymy of Kèdainiai residents (Ragauskaite, 2008, p. 29; Tyla, 2002, p. 27); they cover the period from the seventeenth to the early nineteenth century (1623-1806). A major part of the register books contains entries concerning various events in the town and matters of the local community (inheritance, mortgage, sale and purchase agreements, debt documents, guild statutes, etc.). Records of town council sessions, meetings and town courts go back to 1759 and include several sets: 1759-1763, 1767-1773, 1777-1792 (Tyla, 1999, p. 65).

\footnotetext{
${ }^{2}$ See a list of archival sources at the end of the article.
} 
The volume of the books varies: the largest of them (1756-1758) contains 627 pages, while the smallest one has only 84 pages (1732-1740).

Clerks responsible for town register books had set formulas which they partly followed to make a record of people and court case decisions (Jablonskis, 1979, p. 222). It has been established that the entries were written by seventeen clerks (Tyla, 1999, pp. 73-75), e.g. 1744 Melcher Bowk Pisarz Magdeburgij Kieydanskiey KAK ${ }_{7} 2$ v; ${ }^{3}$ 1769 P[an $]^{4}$ Adam Ciołkiewicz Pisarz $\mathrm{KAK}_{15}$ 78; 1724 Symona Czyzewskiego Pisarza Magdeburyi Kieydan[skiei] gen. sg. ${ }^{5} \mathrm{KAK}_{4}$ 107; 1759 Pan Jozeff Dumaszewicz ktory podziękowawszy Miastu za Elekcya Mieysce Pisarskie KAK ${ }_{10} 1 ; 1762$ Marcinem Grybassem Pisarzem abl. sg. $\mathrm{KAK}_{9}$ 23; 1770 Szlachetny [...] P[an] Jan Gulbin Pisarz KAK $_{15}$ 90; 1665 Woyciech Kalinowski Pisarz Kieydanski KAK 1 51v; 1763 Stanisławem Lubenem Protunc Pisarzem y Całym Szlachetnym Magistratem abl. sg. KAK ${ }_{14} 23 ; 1771$ Pan Ignacy Łukaszewicz Pisarz KAK 16 7; 1765 Mikołajem Judabanem Markowskim

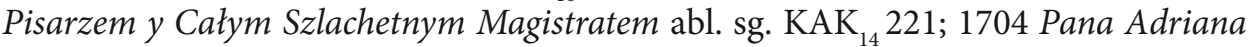
Miłoszewskiego Pisarza [...] Kieydanskiego gen. sg. $\mathrm{KAK}_{3} 4 \mathrm{v} ; 1762$ Stefanem Mixiewiczem Protunc Pisarzem abl. sg. $\mathrm{KAK}_{13}$ 41; 1794 Benedykt Rudelewicz Pisarz Magistratu Miasta [...] wolnego Kieydan $\mathrm{KAK}_{24}$ 142; 1756 Jozefem Antonim z Bończa Rudkowskim przysieglym Magdeburyi Kieydanskiey Pisarzem abl. sg. $\mathrm{KAK}_{12}$ 105, also 1753 Jozefem Antonim z Boncza Rutkowskim Pisarzem abl. sg. KAK ${ }_{11}$ 109; 1774 Michat Symonowicz Protunc Pisarz $\mathrm{KAK}_{10}$ 16; 1764 Kazimierzem Walentynowiczem Protunc Pisarzem abl. sg. KAK 1407.

The surnames of clerks responsible for the books under consideration are known from the sources, and their etymology suggests that most of them were Polish. The ethnicity of the clerks and their individual preferences could have influenced the methods of Polonisation of Lithuanian anthroponyms. These extralinguistic factors had an impact on the writing of Lithuanian historical personal names of Kedainiai residents.

The following major research methods are used to discuss the data of historical anthroponymy: descriptive, reconstructive and comparative (Ragauskaite, 2005, p. 31). From all of the discussed seventeenth- and eighteenth-century records, 505 cases of names of Kèdainiai residents were selected (using two or three personal names). The study also includes calculations of different types of anthroponyms, i.e. suffixal and those with different endings.

${ }^{3}$ All anthroponyms presented in the article are recorded in sources. Each name comes with the year of the record, the abbreviation of the source and page number. This presentation of anthroponyms of Kedainiai residents aims to preserve the original writing, which means that it is different from the tradition of historical source publications (based on Lepszy, 1953, pp. 7-15; Wolff, 1957, pp. 155-181).

${ }^{4}$ Abbreviations used in the sources are written in full, with the supplied part in square brackets.

${ }^{5}$ Abbreviations: abl. - ablative; cur. - current; dat. - dative; gen. - genitive; n. - name; sg. - singular; sur. - surname. 


\section{Naming trends in the seventeenth and eighteenth centuries}

It is important to determine clearly which anthroponyms from the seventeenth- and eighteenth-century records under consideration are attributable to residents of $\mathrm{Ke}$ dainiai. The sources do not provide them on separate lists but in various types of entries. The identification criteria for the selection of personal names of townspeople have been discussed in literature (Ragauskaite, 1999, p. 146, 2000, p. 94, 2003, p. 82, 2004, pp. 8-9, 2005, pp. 18-23, 2006, pp. 81-82, 2014, p. 9, 2015, pp. 59-61). Members of the local community of Kedainiai are easily distinguishable since they are referred to using the designations mieszczanin, obywatel in Polish and indicators of their post or occupation (artisan, craftsman, councillor, etc.), e.g. ${ }^{\star} D e b e i k a,{ }^{\star} D e$ be ikis : 1705 Symon Debeykiewicz Rayca Kieydanski KAK 10 - 1704 Pana Szymona Debeykowicza Raycy Kieydanskiego gen. sg. KAK 3 v, cf. cur. sur. Debeikà, Debeĩkis (LPŽ, 1985-1989, vol. 1, p. 477); ${ }^{\star} G$ in eit a s: 1767 Stawetnego Kaspera Gineytowicza Maystra Kunfztu Gancarskiego y Decemvira gen. sg. $\mathrm{KAK}_{15}$ 7, cf. cur. sur. Gineitas (LPŽ, 1985-1989, vol. 1, p. 670); ${ }^{\star}$ Ke me ras: 1633 Ja Piotr Dawidowicz Kiemeras Mieszczanin $\mathrm{KAK}_{1}$ 5, cf. cur. sur. Kẽmeras (LPŽ, 1985-1989, vol. 1, p. 970); ${ }^{\star} M$ in ga il a: 1722 Utsiwego Jana Mingayly obywatela Kieydanskiego gen. sg. $\mathrm{KAK}_{4} 29 \mathrm{v}$, cf. cur. sur. Mingáila (LPŽ, 1985-1989, vol. 2, p. 249).

The naming system of Kèdainiai residents varied. The selected personal names contain surnames with Lithuanian morphemes (stems, endings and suffixes). The first components of these personal names are Christian names, most frequently in traditional (Polish or Latin) forms. The names of Kedainiai residents of Lithuanian ethnicity were also compared with modern Lithuanian names, e.g. 1691 Adam $^{6}$ $\mathrm{KAK}_{2}$ 45v; 1792 Adamus KKK 447; cf. cur. n. Adõmas (LVKŽ, 1985, p. 61); 1691 Andrzeia gen. sg. KAK $27 \mathrm{v} ; 1779$ Androe gen. sg. KKK 333; 1714 Andrzey KAK 3 35; cf. cur. n. Andriẽjus (LVKŽ, 1985, p. 74); 1765 Antonim abl. sg. KAK ${ }_{10} 110$; cf. cur. n. Antãnas (LVKŽ, 1985, p. 76); 1690 Bartłomieia gen. sg. KAK 2 28; 1774 Bałtromieiowi dat. sg. $\mathrm{KAK}_{17}$ 23; cf. cur. n. Baltramiẽjus (LVKŽ, 1985, p. 89); 1755 Casimirus KKK 29; 1716 Kazimierz KAK 3 75v; cf. cur. n. Kazimieras (LVKŽ, 1985, p. 223); 1733 Dawida gen. sg. KAK 533 ; cf. cur. n. Dóvydas (LVKŽ, 1985, p. 128); 1785 Franciscus KKK 264; cf. cur. n. Pranciškus (LVKŽ, 1985, p. 302); 1667 Gabrielem abl. sg. KAK 65; cf. cur. n. Gabriẽlius (LVKŽ, 1985, p. 160); 1680 Georgius KAK 189 ; 1760 Georgius KKK 93; 1764 Jerzy KAK $_{10}$ 87; cf. cur. n. Jùrgis (LVKZ̆, 1985, p. 215); 1776 Jakub $\mathrm{KAK}_{17} 184$; cf. cur. n. Jokūbas (LVKŽ, 1985, p. 207); 1674 Jana gen. sg. KAK $189 ; 1774$ Ianowi dat. sg. $\mathrm{KAK}_{17}$ 23; 1770 Jan $\mathrm{KAK}_{15}$ 90; 1769 Joannes $\mathrm{KKK} 239$; cf. cur. n. Jõnas (LVKŽ, 1985, p. 208); 1679 Jozefa gen. sg. KAK 1 100; 1754 Josephus KKK 15; 1777

${ }^{6}$ The names are listed in alphabetical order; various forms of the names are included; for reasons of space, only one page number where a particular form appears is provided. 
Jozeff $\mathrm{KAK}_{18}$ 1; 1768 Jozefowi dat. sg. $\mathrm{KAK}_{15}$ 45; cf. cur. n. Juõzapas (LVKŽ, 1985, p. 214); 1780 Kaspera gen. sg. $\mathrm{KAK}_{20}$ 50; cf. cur. n. Kãsparas (LVKŽ, 1985, p. 222); 1690 Krzystof $\mathrm{KAK}_{2} 20 \mathrm{v}$; cf. cur. n. Kristofòras (LVKZ̆, 1985, p. 237); 1633 Macieia gen. sg. $\mathrm{KAK}_{1}$ 2; 1785 Maciey $\mathrm{KAK}_{21}$ 47; 1755 Mathias KKK 30; cf. cur. n. Motiẽjus (LVKŽ, 1985, pp. 279-280); 1753 Marcin KAK 2 198; cf. cur. n. Martỹnas (LVKŽ, 1985, pp. 264-265); 1719 Michael $\mathrm{KAK}_{3}$ 91v; cf. cur. n. Mikalõjus (LVKŽ, 1985, p. 270); 1786 Michał $\mathrm{KAK}_{22}$ 103v; cf. cur. n. Mýkolas (LVKŽ, 1985, p. 270); 1633 Piotr KAK 1 5; cf. cur. n. Pẽtras (LVKŽ, 1985, p. 299); 1690 Symona gen. sg. KAK 2 15v; 1752 Symonem abl. sg. KAK 8 301; cf. cur. n. Simonas (LVKŽ, 1985, p. 329); 1680 Stanisław $\mathrm{KAK}_{1}$ 71; 1753 Stanislaus KKK 7; 1777 Stanisława gen. sg. KAK 19 4v; cf. cur. n. Stanislovas (LVKŽ, 1985, p. 335); 1682 Stephan KAK 13 ; 1742 Stefan KAK 6 217; 1714 Stephana gen. sg. KAK 3 38; cf. cur. n. Stẽponas (LVKŽ, 1985, p. 336); 1775 Thome KKK 292; cf. cur. n. Tòmas (LVKŽ, 1985, p. 350); 1623 Urbana gen. sg. KAK 1; cf. cur. n. Ürbonas (LVKŽ, 1985, pp. 353-354); 1691 Wawrzyniec $\mathrm{KAK}_{2} 43 ; 1763$ Laurentio KKK 145; cf. cur. n. Laurỹnas (LVKŽ, 1985, p. 242); 1634 Woyciech KAK 1 ; cf. cur. n. Vaitiẽkus (LVKŽ, 1985, p. 361). What needs to be noted is the abundance of graphic variants used to write the names of town residents. However, it is surnames or personal names used in their stead that are the primary focus of this study.

\section{Polonisation trends particular to anthroponyms of the seventeenth and eighteenth centuries}

As mentioned above, historical documents of Kedainiai were written by clerks whose native tongue was probably mostly Polish. Therefore, when recording anthroponyms of Lithuanian origin they conveyed their forms in various ways. Some personal names, especially in earlier records from the seventeenth century, are conveyed rather faithfully (with Lithuanian patronymic suffixes -aitis, -ènas, -(i)onis, -(i)ünas, and Lithuanian endings -as, -is), e.g. ${ }^{\star}$ Grigel a it is: 1691 Andrzeia Grigielaycia gen. sg. $\mathrm{KAK}_{2} 37 \mathrm{v}$; cf. cur. sur. Grigeláitis (LPŽ, 1985-1989, vol. 1, p. 713); ${ }^{\star}$ Kudla it is: 1690 Bartłomieia Fiedorowicza alias Kudłaycia gen. sg. $\mathrm{KAK}_{2} 28$; such a surname does not function in present-day anthroponymy; regarding kudl-, cf. cur. sur. Kudlà, Kùdlas, Kùdlis (LPŽ, 1985-1989, vol. 1, p. 1102); ${ }^{\star} L$ ap i en a it is: 1691 Uczciwemu Panu Macieiowi Lapienayciowi dat. sg. $\mathrm{KAK}_{2} 26$; such a surname does not function in present-day anthroponymy; regarding lapien-, cf. cur. sur. Lapienas, Lapiené, Lapiẽnis, Lapienius (LPŽ, 1985-1989, vol. 2, p. 23); ${ }^{\star}$ Martynaitis: 1691 Juzefa Martynaycia gen. sg. KAK 237 v; cf. cur. sur. Martynáitis (LPŽ, 1985-1989, vol. 2, p. 167); ${ }^{\star}$ La b u t i s: 1690 Uczciwego Symona Labucia gen. sg. $\mathrm{KAK}_{2} 15 \mathrm{v}$; cf. cur. sur. Labùtis (LPŽ, 1985-1989, vol. 2, p. 13); ${ }^{*}$ Plač iakis: 1634 Ja Woyciech Płaczekis Mieszczanin Miasta KAK 7 - 1633 Mieszczaninowi Kieydanskiemu Woyciechowi 
Jakubowiczowi Placiakiowy dat. sg. KAK 1 2; cf. cur. sur. Plãčiakis (LPŽ, 1985-1989, vol. 2, p. 466); ${ }^{\star S} u k i$ s, ${ }^{\star} \check{S} u k y s: 1633$ Macieia Szukia gen. sg. $\mathrm{KAK}_{1} 2$; cf. cur. sur. Šùkis, Šukỹs (LPŽ, 1985-1989, vol. 2, pp. 986-987).

However, the greater part of anthroponyms was altered in a variety of ways. This also stemmed from linguistic factors, especially the interplay between the Lithuanian and Polish languages (Būga, 1958, p. 232; Falk, 1963, pp. 88-94, 1966, pp. 4-7; Garliauskas, 1998, pp. 124-202, 2000, pp. 232-244, 2004, pp. 24-30; Maciejauskiené, 1989, pp. 67-68, 1991, pp. 173-177; Ragauskaite, 2005, pp. 61-66, 2015, pp. 63-64, 2018b, pp. 57-58, 2019, pp. 182-183; Safarewicz, 1950, pp. 113-119; Sinkevičiūte, 2016, pp. 223-229; Sinkevičiūtė \& Račickaja, 2014, pp. 297-300; Zinkevičius, 1977, pp. 127-129, 2008, pp. 57-65). The most frequent alterations were as follows:

- a replaced with $o$, e.g. ${ }^{\star} B$ a na it is: $1691 \mathrm{Ja}$ Wawrzyniec Lubenas alias Bonaytis Mieszczanin Miafta Kieydan $\mathrm{KAK}_{2}$ 43; cf. cur. sur. Banáitis (LPŽ, 1985-1989, vol. 1, p. 184); ${ }^{*}$ Rimdeika: 1720 Ja Jan Rymdeyko [...] Obywatele Miasta KAK $399 \mathrm{v}$; cf. cur. sur. Rimdeikà (LPŽ, 1985-1989, vol. 2, p. 608); ${ }^{\star}$ Skirgaila: 1761 P[an] Ian Skirgayłło KAK 1049 - 1795 Ja Jan Skirgayło Obywatel Miafta Kieydan $\mathrm{KAK}_{24} 51 ; 1797$ $P[a n]$ Marcin Skirgayło Ob[ywatel] Kieydańfki $\mathrm{KAK}_{24}$ 119v; cf. cur. sur. Skirgáila (LPŽ, 1985-1989, vol. 2, p. 742);

- au replaced with ow: ${ }^{*}$ D a u j o ta s: 1733 Dawida Dowiata gen. sg. KAK 33 ; cf. cur. sur. Dáujotas (LPŽ, 1985-1989, vol. 1, p. 471); ‘Sk a u m in a s: 1665 Pana Piotra Zygmontowicza Skowmina [...] Burmistrzow Rajcow Ławnikow Miasta gen. sg. KAK ${ }_{1}$ 47; cf. cur. sur. Skaũminas (LPŽ, 1985-1989, vol. 2, p. 733);

- e replaced with ie: ${ }^{*}$ Gedeika: 1768 utsciwy Jan Giedeyko $\mathrm{KAK}_{15}$ 36; 1785 Maciey Giedeyko $\mathrm{KAK}_{21}$ 47; cf. cur. sur. Gedeikà (LPŽ, 1985-1989, vol. 1, p. 639); ${ }^{*}$ Ke tv irt is: 1623 od domu Urbana Kietwircia gen. sg. KAK 1 1; cf. cur. sur. Ketvirtis (LPŽ, 1985-1989, vol. 1, p. 981);

- o replaced with $a:{ }^{*} J o$ m a n ta s: 1667 Gabrielem Jamontem Burmiftrzami Ławnikami abl. sg. $\mathrm{KAK}_{1}$ 65; 1714 Stephana Jamonta Lawnika Kieydan[skiego] gen. sg. $\mathrm{KAK}_{3} 38$; cf. cur. sur. Jómantas, Jõmantas, Jomantas (LPŽ, 1985-1989, vol. 1, pp. 840-841).

The existing data demonstrates the tendency to add Slavic suffixes - evič and -ovič, e.g. ${ }^{\star} K u n k u l i s,{ }^{\star} K u n k u l y s: 1691$ Ja Adam Janowicz Kunkulewicz [...] Mieszczanie Miasta Kieydan $\mathrm{KAK}_{2} 34 ; 1691$ Panu Janie Kunkulewiczu dat. sg. $\mathrm{KAK}_{2} 34 \mathrm{v}$; cf. cur. sur. Kuñkulis, Kunkùlis (LPŽ, 1985-1989, vol. 1, p. 1124); ${ }^{\star} K u \operatorname{tra},{ }^{\star} K u \operatorname{try} s: 1690$ Krzystof Kutrewicz Ławnik KAK 2 20v; cf. cur. sur. Kutrà, Kutrỹs (LPŽ, 1985-1989, vol. 1, p. 1142); ${ }^{\star}$ Mantvilas: 1691 Ja Woyciech Mątwiłowicz Mieszczanin Miasta Kieydan $\mathrm{KAK}_{2} 47$; cf. cur. sur. Mañtvilas, Mantvilas, Mantvilas (LPŽ, 1985-1989, vol. 2, p. 156); ${ }^{\star}$ Plikis, ${ }^{*}$ Plikys: 1674 Pana Jana Plikowicza gen. sg. KAK 1 89; cf. cur. sur. Plikis, Plikỹs (LPŽ, 1985-1989, vol. 2, p. 476); ${ }^{\star} R$ i m ša a ${ }^{*} R$ i mš is: 1762 Symon Rymfzewicz KAK ${ }_{10}$ 157; cf. cur. sur. Rimša, Rimšis (LPŽ, 1985-1989, vol. 2, p. 611). 
Also, there are some instances when surnames of Kedainiai residents are written without endings, e.g. ${ }^{\star} G$ ulb i n a s: 1794 Jerzy Gulbin $\mathrm{KAK}_{24}$ 5; 1782 Ja Kazimierz Gulbin Radca M[iasta] Kejdan $\mathrm{KAK}_{21}$ 2v; 1753 Pan Marcin Gulbin Obywa[tel] Kiey[danski] $\mathrm{KAK}_{2}$ 198; cf. cur. sur. Gulbinas (LPŽ, 1985-1989, vol. 1, p. 741); ${ }^{\star} L$ u b è nas: 1788 Ja Bartłomiey Luben Mayster Kunsztu Kowalskiego y Obyw[atel] Kieydan[ski] $\mathrm{KAK}_{21}$ 82v; 1777 Uczciwi Jozeff Luben $\mathrm{KAK}_{18}$ 1; 1764 Uczciwy Maciey Luben O[bywatel] Kieydan[ski] $\mathrm{KAK}_{10}$ 97; 1759 Stanisław Luben Decemvirowie $\mathrm{KAK}_{10} 8 ; 1777$ Uczciwy Stefan Luben $\mathrm{KAK}_{18}$ 2; such a surname does not function in present-day anthroponymy; regarding lub-, cf. cur. sur. Lùbas, Lubáuskas, Lubenskas, Lubỹs (LPZ̆, 1985-1989, vol. 2, p. 109); *S ta n kü n a s: 1680 Stanistaw Stankun Miefczanin Miasta [...] Kieydan KAK, 71; cf. cur. sur. Stankūnas (LPZ̆, 1985-1989, vol. 2, p. 804).

An exhaustive investigation into personal names of Kedainiai residents in the seventeenth century in terms of their formation revealed that in this period the most productive were patronymic suffixes -evič (203, i.e. 22.4\%) and -aitis (106, i.e. $11.7 \%)$. Besides, the Kedainiai inventory of 1666 has an evident increase in anthroponyms with suffixes of the -sk- type (1604: 10 personal names (1.10\%), 1666: 60 anthroponyms (6.62\%)). This clearly indicates the Polonisation of personal names (Ragauskaitè, 2018a, pp. 111-112).

Kedainiai register books from the eighteenth century indicate an obvious predominance of town resident surnames with Slavic suffixes -evič, -ovič, e.g. ${ }^{\star} B u d r$ is, ${ }^{\star} B$ udrys: $1704 P[a n a]$ Jozefa Budrewicza Woyta teraznieyszego Kieydanskiego gen. sg. $\mathrm{KAK}_{3} 3$; cf. cur. sur. Bùdris, Budrỹs (LPŽ, 1985-1989, vol. 1, p. 330); ${ }^{\star}$ Ma ntrimas: 1765 z Uczciwym Antonim Montrimowiczem abl. sg. KAK 10 110; 1775 Michałowi Montrimowiczowi Obyw [atelowi] Kieydan [skiemu] dat. sg. $\mathrm{KAK}_{17} 112$; cf. cur. sur. Mantrimas, Mañtrimas, Mantrimas (LPŽ, 1985-1989, vol. 2, p. 155); ${ }^{\star}$ Nor butas: 1714 sławney Pamięci Andrzeiu Narbutowiczu na Ulicy Konskiey dat. sg. KAK 6 67; cf. cur. sur. Nórbutas (LPŽ, 1985-1989, vol. 2, p. 332); ${ }^{\star}$ Nor m a n tas: 1719 Michael Narmontowicz KAK 3 91v; cf. cur. sur. Nórmantas, Normantas (LPŽ, 1985-1989, vol. 2, p. 335); ${ }^{\star S}$ a p a la s: 1785 Jerzy Szapał $\mathrm{KAK}_{22} 67-1785$ Jerzy Szapałas $\mathrm{KAK}_{22}$ 16 - 1796 Jerzy Szappałłowiczi dat. sg. $\mathrm{KAK}_{24}$ 89; cf. cur. sur. Šãpalas (LPŽ, 19851989, vol. 2, p. 886).

However, single cases of surnames with Lithuanian endings or suffixes could still be found during this period as well, e.g. ${ }^{\star} B u$ ivyd as: 1780 Jozefowi Buywidowi Maystrom Cechu Szwieckiego dat. sg. $\mathrm{KAK}_{20} 74 ; 1780$ Uczciwych Macieja Buywida [...] Maystrow Kunsztu Szwieckiego gen. sg. $\mathrm{KAK}_{20} 6 ; 1723$ z Ucciwym Stanislawem Buywidem abl. sg. $\mathrm{KAK}_{4}$ 87; cf. cur. sur. Bùivydas, Buĩvydas, Buivydas (LPŽ, 1985-1989, vol. 1, p. 337); ${ }^{\star}$ G u sta s: 1786 Uczciwy Michat Gustas Mayster Kunsztu Ciesielskiego $\mathrm{KAK}_{22}$ 103v - 1764 Michał Gusttas $\mathrm{KAK}_{10}$ 87; cf. cur. sur. Gùstas (LPŽ, 1985-1989, vol. 1, p. 748); ${ }^{*}$ Mantvydas: 1780 Georgius Montwid KAK 1 89; cf. cur. sur. Mañtvydas, Mantvydas (LPŽ, 1985-1989, vol. 2, p. 155); ${ }^{\star}$ Mikš ta s: 1796 Jozeff Miksztas 
Teść [...] Obywatele Kieydańscy $\mathrm{KAK}_{4}$ 80; cf. cur. sur. Mikštas (LPŽ, 1985-1989, vol. 2, p. 233); ${ }^{\star}$ Pa ves s is: 1765 Janowi Pawiesiowi Oby[watelowi] Kieyd[anskiemu] dat. sg. KAK $_{10} 148$; cf. cur. sur. Pavesis (LPŽ, 1985-1989, vol. 2, p. 414); ${ }^{\star}$ R a ty s: 1776 Jakub Ratys $\mathrm{KAK}_{17} 184$; such a surname does not function in present-day anthroponymy; regarding rat-, cf. cur. sur. Rãtas, Ratãvičius, Raté, Ratẽlis (LPŽ, 1985-1989, vol. 2, p. 580); ${ }^{*}$ Rep šys : 1774 Ianowi Repsziowi dat. sg. $\mathrm{KAK}_{17}$ 23; cf. cur. sur. Rep̌̌y $\tilde{s}$ (LPŽ, 1985-1989, vol. 2, p. 599); ${ }^{\star}$ Treigys: 1761 Uczciwy Jerzy Treygis [...] Obywatele Kiedanscy $\mathrm{KAK}_{10}$ 50; cf. cur. sur. Treigỹs (LPŽ, 1985-1989, vol. 2, p. 1064); ${ }^{*}$ Virbalas: 1730 Jakuba Wirbała [...] w Miescie Kieydanach gen. sg. $\mathrm{KAK}_{2}$ 60; cf. cur. sur. Virbalas (LPŽ, 1985-1989, vol. 2, p. 1227).

Some surnames were still recorded with Lithuanian patronymic suffixes -aitis, -ènas, -(i)onis, -(i)ünas, e.g. ${ }^{\star}$ Ka pla it is: 1716 Ja Kazimierz Kaplaytis stolarz $\mathrm{KAK}_{3}$ $75 \mathrm{v}$; such a surname does not function in present-day anthroponymy; regarding kapl-, cf. cur. sur. Kapliáuskas, Kãplonas (LPŽ, 1985-1989, vol. 1, p. 916); ${ }^{*}$ Kazeraitis: 1777 Stanisława Kazeraycia gen. sg. $\mathrm{KAK}_{17} 215$; such a surname does not function in present-day anthroponymy; regarding kazer-, cf. cur. sur. Kazeráuskas (LPŽ, 19851989, vol. 1, p. 957); ${ }^{\star}$ Matijo ša it is: 1767 Uczciwym [...] Janowi Matiosiaycziowi dat. sg. $\mathrm{KAK}_{10} 148$; cf. cur. sur. Matijošáitis (LPŽ, 1985-1989, vol. 2, p. 180); ${ }^{\star} M a-$ tula it is: 1704 D[omini] Francisci Matulaytys $\mathrm{KAK}_{3}$ 4; cf. cur. sur. Matuláitis (LPŽ, 1985-1989, vol. 2, p. 183); ${ }^{\star}$ P a u li u ka it is: 1714 Uczciwy Andrzey Paulukaytis [...] obywatele Miasta Kieydan KAK 3 35; cf. cur. sur. Pauliukáitis (LPŽ, 1985-1989, vol. 2, p. 410); ${ }^{\star}$ S te 1 m a cha it is: 1733 z Ucciwym Marcinem Stelmachayciem abl. sg. $\mathrm{KAK}_{5}$ $16 \mathrm{v}$; such a surname does not function in present-day anthroponymy; regarding stelmach-, cf. cur. sur. Stelmokáitis (LPŽ, 1985-1989, vol. 2, p. 816); ${ }^{\star S}$ i m a it is: 1704 Jakub Szimaytis [...] Mieszczanie Miasta Kieydan $\mathrm{KAK}_{3}$ 4; cf. cur. sur. Šimáitis (LPŽ, 1985-1989, vol. 2, p. 928); ${ }^{\star}$ Mat ul io n is: 1762 Stanisława Matulonia Obyw[atela] Kieydan[skiego] gen. sg. $\mathrm{KAK}_{10}$ 70; cf. cur. sur. Matuliónis (LPŽ, 1985-1989, vol. 2, p. 183); ${ }^{*}$ Ba č el i ūn as: 1797 Maciey Baczelunas Mayster $\mathrm{KAK}_{24}$ 123; 1797 Uczciwy Michał Baczelunas Obyw[atel] Kieydan[ski] $\mathrm{KAK}_{24}$ 123; 1796 Ja Szymon Baczelunas Obywatel Kieydanski $\mathrm{KAK}_{24} 58 \mathrm{v}$; such a surname does not function in present-day anthroponymy; regarding bačel-, cf. cur. sur. Bačẽlis (LPŽ, 1985-1989, vol. 1, p. 150); ${ }^{*}$ Grigali ūnas: 1770 Macieia Grygaluna Obywatela Kieydanskiego gen. sg. $\mathrm{KAK}_{15}$

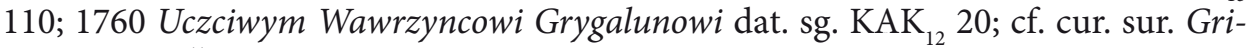
galiūnas (LPŽ, 1985-1989, vol. 1, p. 711); ${ }^{*}$ Kris č i ū nas: 1791 Mathioe Krisciunowi dat. sg. $\mathrm{KAK}_{23}$ 6; 1776 Michał Krysciunas $\mathrm{KAK}_{17}$ 171; cf. cur. sur. Krisčiūnas (LPŽ, 1985-1989, vol. 1, p. 1079); ${ }^{*}$ r ranck ū nas: 1723 Stefana Pranckuna gen. sg. KAK ${ }_{4}$ 79v; cf. cur. sur. Pranckūnas (LPŽ, 1985-1989, vol. 2, p. 503).

The above examples of surname Polonisation, particular to the seventeenth and eighteenth centuries, indicate that authentic Lithuanian anthroponyms of Kedainiai residents were modified in different ways. Therefore, in the spoken language these 
people were referred to differently than recorded in the analysed sources. Clearly, this attests to interlaced traditions of written Polish and spoken Lithuanian. The article presents the most characteristic distinctive features particular to the recording of personal names of Kedainiai residents on the basis of records in historical documents rather than the spoken language. This stems from the nature of analysed historical sources, their context, the skills of clerks, and from various social status of particular individuals who appear in them. Long records of meetings and court sessions were handwritten, with very few recording formulas being used. In these large-scale historical records, names and surnames were only elements of the text.

It can be observed that Slavicisation had a different impact on the recording of names of town residents in Kedainiai documents of administrative nature and church registers from the eighteenth century. This can be demonstrated on the basis of the 1752-1799 register of christenings kept by St George's Church of Kedainiai Parish. This Catholic parish church provided christenings for children of Kèdainiai residents and peasants from surrounding villages. These people were mostly Lithuanians, and their names preserved Lithuanian suffixes and endings. Only those cases were selected which had an indication Keydany. The surnames are those of godparents and parents of christened children. They have Lithuanian endings and patronymic suffixes -aitis (written-aytis), -(i)onis (written -(i)onis), -(i)ünas (written -(i)unas) and the diminutive suffix -ulis (written -ulis), e.g. ${ }^{*} A$ bro m a it is: 1754 Josephus Abromaytis [...] Keydany KKK 15; cf. cur. sur. Abromáitis (LPŽ, 1985-1989, vol. 1, p. 60); ${ }^{\star} L$ a u ry na it is: 1756 Georgio Eawrynaytis [...] Keydany KKK 41; cf. cur. sur. Laurynáitis (LPŽ, 1985-1989, vol. 2, p. 35); ${ }^{\star}$ Lu koša it is: 1769 Joannes Łukaszaytis [...] Keydany KKK 239; cf. cur. sur. Lukošáitis (LPŽ, 1985-1989, vol. 2, p. 114); ${ }^{\star} M y$ k o la it is : 1756 Georgius Mikołaytis [...] Keydany KKK 41; cf. cur. sur. Mýkolaitis, Mykoláitis, Mykolaitis (LPŽ, 1985-1989, vol. 2, pp. 231-232); ${ }^{\star}$ Petraitis: 1755 Mathias Petraytis [...] Keydany KKK 30; cf. cur. sur. Petráitis (LPŽ, 1985-1989, vol. 2, p. 437); ${ }^{\star}$ Pet rila it is: 1757 Joannes Petryłaytis [...] Keydany KKK 50; cf. cur. sur. Petrilaitis (LPŽ, 1985-1989, vol. 2, p. 441); ${ }^{\star}$ S a ma it is: 1769 Andrea Samaytis [...] Keydany KKK 234; cf. cur. sur. Samáitis (LPŽ, 1985-1989, vol. 2, p. 667); ${ }^{\star}$ B ra zi i o n is: 1785 Franciscus Brazionis [...] Keydany KKK 264; cf. cur. sur. Braziónis (LPŽ, 1985-1989, vol. 1, p. 302); ${ }^{*}$ Ge n io n is: 1780 Josephus Gienionis [...] Keydany KKK 345; cf. cur. sur. Geniónis (LPŽ, 1985-1989, vol. 1, p. 652); ${ }^{\star}$ Je ne li o n is: 1775 Thome Jenelonis [...] Keydany KKK 292; cf. cur. sur. Jeneliónis (LPŽ, 1985-1989, vol. 1, p. 829); ${ }^{\star S}$ ta nio n is: 1792 Adamus Stanionis [...] Keydany KKK 447; cf. cur. sur. Staniónis (LPŽ, 1985-1989, vol. 2, p. 801); ${ }^{\star}$ Kri řč i ün as: 1764 Georgio Kriszcziunas [...] Keydany KKK 179; cf. cur. sur. Kriščiūnas (LPŽ, 1985-1989, vol. 1, p. 1081); ${ }^{\star} P$ la n č i ū nas: 1760 Georgius Płancziunas [...] Keydany KKK 93; cf. cur. sur. Plančiūnas (LPŽ, 19851989, vol. 2, p. 467); ${ }^{\star} R$ a z u lis: 1755 Stanislaus Razulis [...] Keydany KKK 23; cf. cur. sur. Razùlis (LPŽ, 1985-1989, vol. 2, p. 587). 
Kedainiai Reformists of the seventeenth and eighteenth centuries fostered the Lithuanian language. In the Grand Duchy of Lithuania of the seventeenth century, the town of Kedainiai was a Reformist centre of Lithuanianness. In this town, the Mass was said in Lithuanian from the third decade of the seventeenth century until 1785, with a five-year interruption in 1682-1687 (Lukšaité, 1970, pp. 15, 23). The burgomaster Steponas Jaugelis Telega participated in the session of town Reformists which decided to organise books required for the Mass in Lithuanian. The synod was responsible for appointing priests who knew Lithuanian for full-time service in Kèdainiai. The book Knyga nobažnystès [The Book of the Christian Faith] was published in Kèdainiai, not Vilnius. According to Ingè Lukšaitė (Lukšaitė, 2001, pp. 4, 10), it was the most important Lithuanian publication of the century: including four books under one title, it was a sign that over the first half of the seventeenth century the community of the Lithuanian Reformed church - Unitas Lithuaniae (The Evangelical Reformed Church of Lithuania) - experienced significant shifts in its cultural self-awareness. These circumstances clearly demonstrate that the Lithuanian language was used and fostered in the public life of Kedainiai in the seventeenth and eighteenth centuries. To some extent, these manifestations of Lithuanianness were also reflected in the analysed sources.

\section{Conclusions}

Historical records from the seventeenth and eighteenth centuries (Kèdainiai register books from 1623-1799) were used to extract 505 cases of names of Kedainiai residents. As established, the most frequent was the binary type that used a name and a surname or a personal name that performed the function of the latter. In this model, the first component was a Christian name, most often recorded in a traditional Polish or Latin form.

The results of this study of the historical anthroponymy of Kedainiai indicate that personal names of the seventeenth century were Polonised: cases of phonetic alterations were noted, some surnames had no endings, some Lithuanian patronymic and diminutive suffixes were replaced with Slavic suffixes, and Slavic patronymic suffixes -evič, -ovič were added to names without suffixes.

Most cases of Polonisation of anthroponyms were found in Kèdainiai register books from the eighteenth century. In this period, Slavic patronymic suffixes -evič, -ovič were predominant in surnames of Kèdainiai residents. 


\section{Appendix}

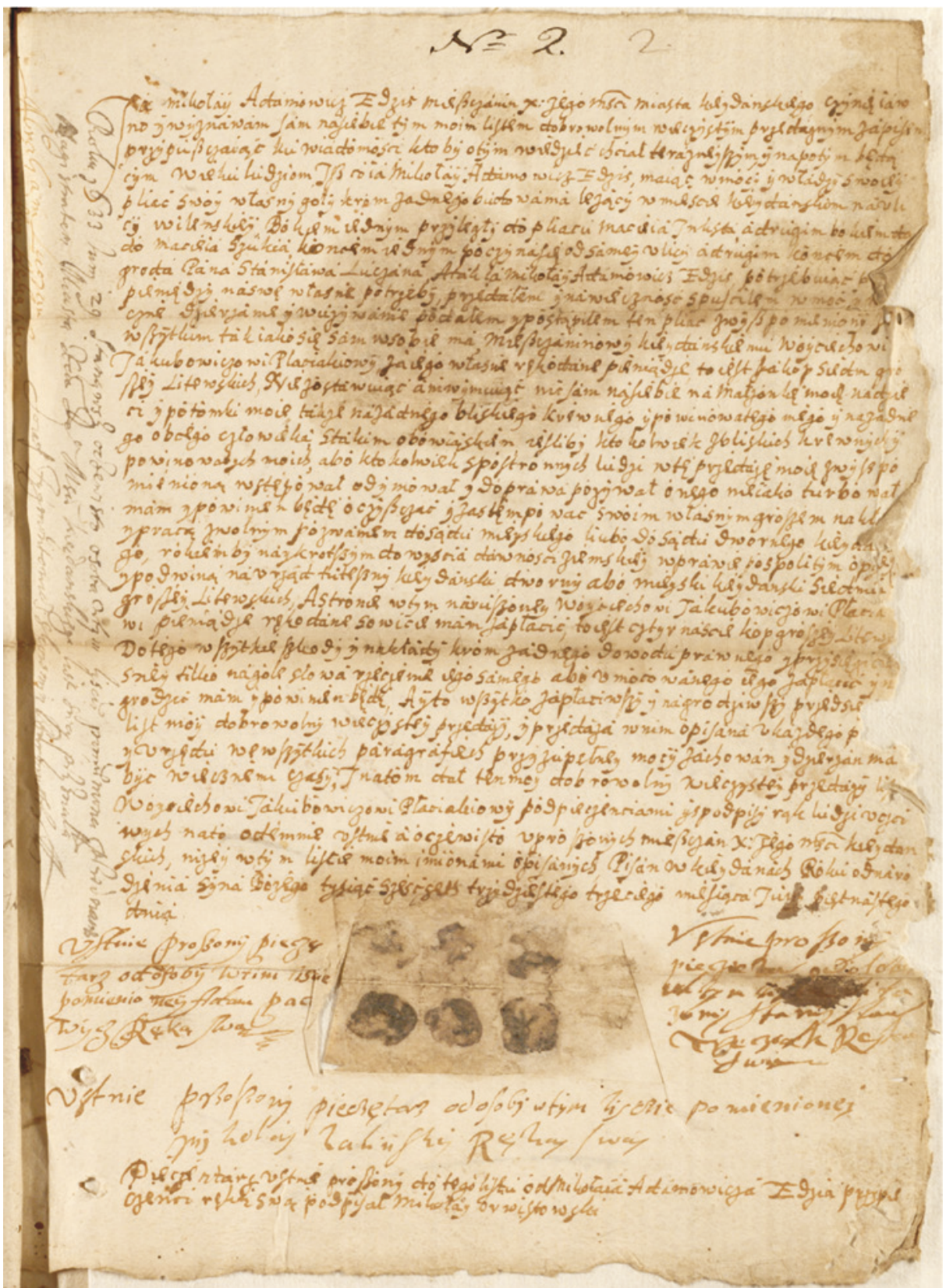

Figure 1: Kèdainiai register book of 1623-1806, passage dated 1633 (p. 2) 


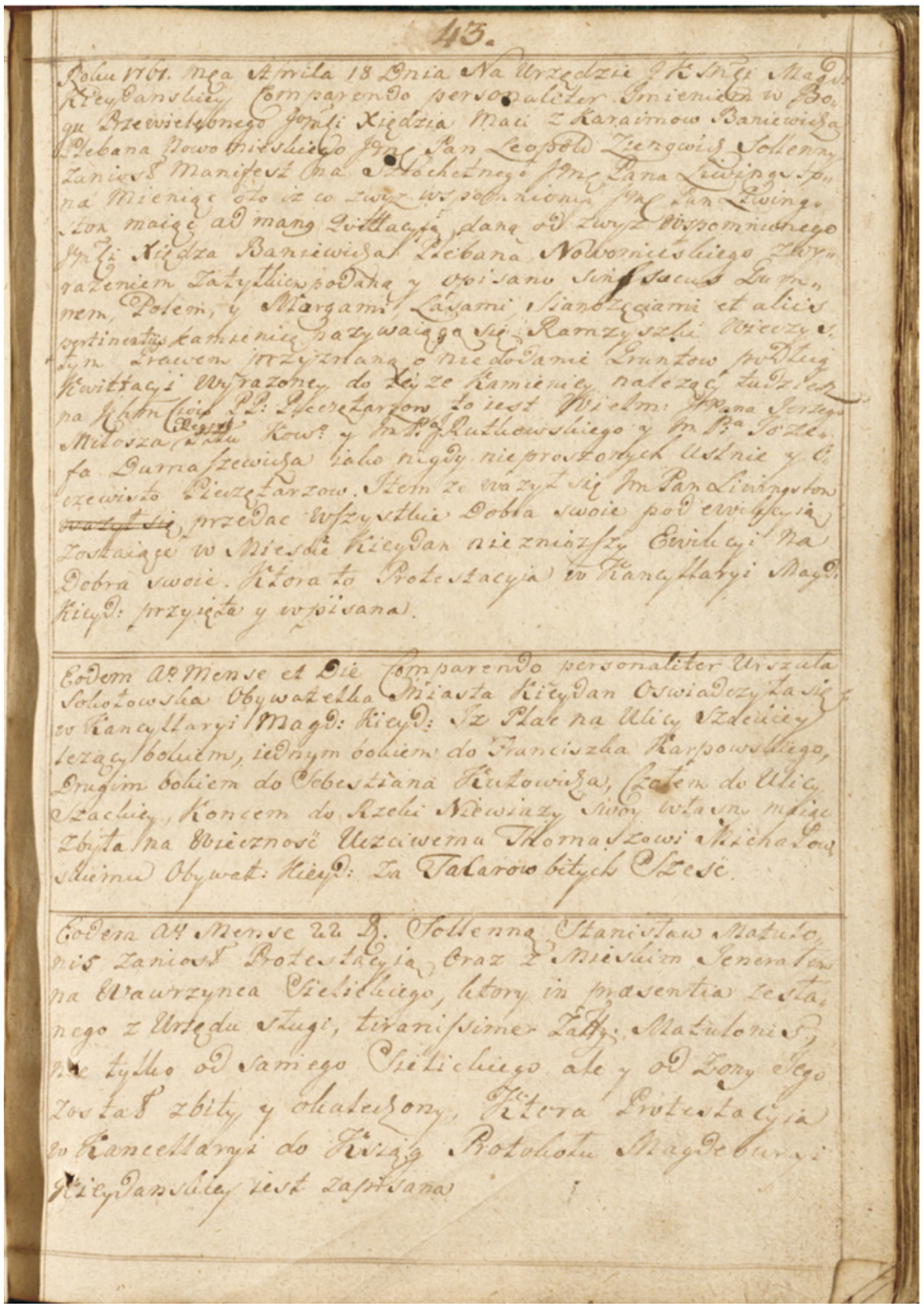

Figure 2: Kèdainiai register book of 1750-1766, passage dated 1761 (p. 43) 


\section{Archival sources}

$\mathrm{KAK}_{1}$ - Kèdainių 1623-1806 m. aktų knyga [Kèdainiai register book, 1623-1806]. Lietuvos valstybès istorijos archyvas [Office of the Chief Archivist of Lithuania], hereafter LVIA, f. SA, b. 15360 .

$\mathrm{KAK}_{2}$ - Kèdainių aktų 1690-1775 m. knyga [Kèdainiai register book, 1690-1775]. LVIA, f. SA, b. 15357.

$\mathrm{KAK}_{3}$ - Kèdainių aktų 1704-1720 m. knyga [Kèdainiai register book, 1704-1720]. LVIA, f. SA, b. 15358 .

$\mathrm{KAK}_{4}$ - Kèdainių aktų 1721-1725 m. knyga [Kèdainiai register book, 1721-1725]. LVIA, f. SA, b. 15359.

$\mathrm{KAK}_{5}$ - Kèdainių aktų 1732-1740 m. knyga [Kèdainiai register book, 1732-1740]. LVIA, f. SA, b. 15361.

$\mathrm{KAK}_{6}$ - Kèdainių aktų 1732-1743 m. knyga [Kèdainiai register book, 1732-1743]. LVIA, f. SA, b. 15362.

$\mathrm{KAK}_{7}$ - Kèdainių aktų 1744-1750 m. knyga [Kèdainiai register book, 1744-1750]. LVIA, f. SA, b. 15363.

$\mathrm{KAK}_{8}$ - Kèdainių aktų 1750-1752 m. knyga [Kèdainiai register book, 1750-1752]. LVIA, f. SA, b. 15364 .

$\mathrm{KAK}_{9}$ - Kèdainių aktų 1750-1761 m. knyga [Kèdainiai register book, 1750-1761]. LVIA, f. SA, b. 15367.

$\mathrm{KAK}_{10}$ - Kèdainių aktų 1750-1766 m. knyga [Kèdainiai register book, 1750-1766]. LVIA, f. SA, b. 15368 .

$\mathrm{KAK}_{11}$ - Kèdainių aktų 1753-1755 m. knyga [Kèdainiai register book, 1753-1755]. LVIA, f. SA, b. 15365 .

$\mathrm{KAK}_{12}$ - Kèdainių aktų 1756-1758 m. knyga [Kèdainiai register book, 1756-1758]. LVIA, f. SA, b. 15366.

$\mathrm{KAK}_{13}$ - Kèdainių aktų 1762-1763 m. knyga [Kèdainiai register book, 1762-1763]. LVIA, f. SA, b. 15369.

$\mathrm{KAK}_{14}$ - Kèdainių aktų 1763-1770 m. knyga [Kèdainiai register book, 1763-1770]. LVIA, f. SA, b. 15370 .

$\mathrm{KAK}_{15}$ - Kèdainių aktų 1767-1770 m. knyga [Kèdainiai register book, 1767-1770]. LVIA, f. SA, b. 15371.

$\mathrm{KAK}_{16}$ - Kèdainių aktų 1771-1773 m. knyga [Kèdainiai register book, 1771-1773]. LVIA, f. SA, b. 15372 .

$\mathrm{KAK}_{17}$ - Kèdainių aktų 1774-1777 m. knyga [Kèdainiai register book, 1774-1777]. LVIA, f. SA, b. 15373.

$\mathrm{KAK}_{18}$ - Kèdainių aktų 1777-1779 m. knyga [Kèdainiai register book, 1777-1779]. LVIA, f. SA, b. 15374.

$\mathrm{KAK}_{19}$ - Kèdainių aktų 1777-1780 m. knyga [Kèdainiai register book, 1777-1780]. LVIA, f. SA, b. 15375 . 
$\mathrm{KAK}_{20}$ - Kèdainių aktų 1779-1782 m. knyga [Kèdainiai register book, 1779-1782]. LVIA, f. SA, b. 15376 .

$\mathrm{KAK}_{21}$ - Kèdainių aktų 1782-1791 m. knyga [Kèdainiai register book, 1782-1791]. LVIA, f. SA, b. 15377.

$\mathrm{KAK}_{22}$ - Kèdainių aktų 1783-1792 m. knyga [Kèdainiai register book, 1783-1792]. LVIA, f. SA, b. 15378 .

$\mathrm{KAK}_{23}$ - Kèdainių aktų 1791-1806 m. knyga [Kèdainiai register book, 1791-1806]. LVIA, f. SA, b.15379.

$\mathrm{KAK}_{24}$ - Kèdainių aktų 1794-1798 m. knyga [Kèdainiai register book, 1794-1798]. LVIA, f. SA, b. 15380 .

KKK - Kèdainių katalikų Šv. Jurgio bažnyčios krikšto 1752-1799 m. metrikų knyga [Catholic parish in Kèdainiai, St George’s Church register of christenings, 1752-1799]. LVIA, f. 1424, ap. 1, b. 1 .

\section{Abbreviations}

LPŽ - Maciejauskienė, V., Razmukaite, M., \& Vanagas, A. (Ed.). Lietuviu pavardžių žodynas, 1-2. Vilnius: Mokslas, 1985-1989.

LVKŽ - Kuzavinis, K., \& Savukynas, B. Lietuvių vardų kilmés žodynas. Vilnius: Mokslas, 1985.

\section{Bibliography}

Būga, K. (1958). Apie lietuvių asmens vardus. In Z. Zinkevičius (Ed.), Rinktiniai raštai (Vol. 1, pp. 201-269). Valstybinè politinès ir mokslinès literatūros leidykla.

Falk, K. O. (1963). Ze studiów nad slawizacją litewskich nazw miejscowych i osobowych. Scando-Slavica, 9(1), 87-103. https://doi.org/10.1080/00806766308600385

Falk, K.O. (1966). O metodach slawizacji litewskich nazw osobowych i miejscowych. O genezie i rozpowszechnieniu nazw na -ańce. Spräkliga Bidrag, 5(22), 1-16.

Garliauskas, V. (1998). Lietuviškos oikonimų lytys nelietuviškuose XVI-XIX a. šaltiniuose. Acta Linguistica Lithuanica / Lietuviu kalbotyros klausimai, 1998(40), 123-204.

Garliauskas, V. (2000). Lietuviškos asmenvardžių lytys XV amžiaus Lietuvos Metrikos dokumentuose. Baltistica, 35(2), 231-246. https://doi.org/10.15388/baltistica.35.2.574

Garliauskas, V. (2004). XVII a. Molètu bažnyčios krikšto ir santuokos metrikų knyga. Mokslo ir enciklopedijų leidybos institutas.

Jablonskis, K. (1979). Istorija ir jos šaltiniai. Mokslas.

Kuzavinis, K., \& Savukynas, B. (1985). Lietuvių vardų kilmés žodynas [LVKŽ]. Mokslas.

Lepszy, K. (1953). Instrukcja wydawnicza dla źródeł historycznych od XVI do połowy XIX wieku. Zakład Narodowy im. Ossolińskich - Wydawnictwo Polskiej Akademii Nauk. 
Lukšaitè, I. (1970). Lietuvių kalba reformaciniame judejime XVII a. Lietuvos TSR Mokslų akademijos Istorijos institutas.

Lukšaitė, I. (2001). Knygos nobažnystès (1653) parengimo kultūrinè aplinka. In I. Lukšaitė (Ed.), "Knyga nobažnystès krikščioniškos" (1653) - XVII a. Lietuvos kultūros paminklas (pp. 4-28). Kèdainių krašto muziejus.

Maciejauskienè, V. (1989). Kaip slavintos lietuvių pavardès? Kalbos kultūra, 56, 66-69.

Maciejauskienè, V. (1991). Lietuviu pavardžiu susidarymas XIII-XVIII a. Mokslas.

Maciejauskienè, V., Razmukaite, M., \& Vanagas, A. (Eds.). (1985-1989). Lietuviu pavardžiu žodynas [LPŽ] (Vols. 1-2). Mokslas.

Ragauskaitè, A. (1999). XVI a. II pusės Kauno miestiečių lietuviškos kilmės asmenvardžiai. Acta Linguistica Lithuanica / Lietuvių kalbotyros klausimai, 1999(41), 145-158.

Ragauskaite, A. (2000). XVII a. pirmosios pusès Kauno miestiečių asmenvardžių kilmè. Acta Linguistica Lithuanica / Lietuviu kalbotyros klausimai, 2000(43), 93-110.

Ragauskaitè, A. (2003). XVI-XVIII a. kauniečių moterų asmenvardžių daryba. Vārds un tā pètīšanas aspekti. Rākstu krājums, 7, 82-92.

Ragauskaitė, A. (2004). XVI-XVII a. joniškiečių asmenvardžiai. In J. Švambarytė-Valužienė (Ed.), Istoriniai tekstai ir vietos kultūra (pp. 8-18). Lucilijus.

Ragauskaite, A. (2005). XVI-XVIII a. kauniečių asmenvardžiai. Lietuvių kalbos instituto leidykla.

Ragauskaité, A. (2006). Vietovardinès kilmès asmenvardžiai ir prievardžiai XVI a. Kauno aktų knygose. Baltu filologija, 15(1-2), 81-94.

Ragauskaite, A. (2008). Tendencies in the evolution of hereditary surnames of townspeople in Lithuania from the sixteenth to eighteenth centuries. Zunamen / Surnames, 3, 29-37.

Ragauskaite, A. (2014). Kauno moterų asmenvardžiai XVI-XVII a. lietuvių istorinès antroponimijos kontekste. Kauno istorijos metraštis, 14, 7-17.

Ragauskaite, A. (2015). Seniausios Lietuvoje 1599-1621 metų Joniškio krikšto metrikų knygos joniškiečių moterų asmenvardžiai lietuvių istorinès antroponimijos kontekste. Acta Linguistica Lithuanica, 2015(73), 55-81.

Ragauskaite, A. (2016). Škotų pavardžių užrašymo tendencijos XVII-XVIII a. Kèdainių miesto istorijos šaltiniuose. Acta Linguistica Lithuanica, 2016(75), 45-67.

Ragauskaitė, A. (2017a). Germaniškos kilmès kẻdainiečių antroponimai XVII-XVIII a. Kèdainių miesto istorijos šaltiniuose. Baltu filologija, 25(2), 111-128.

Ragauskaitè, A. (2017b). Kèdainiečių (lietuvių, lenkų) pavardžių formavimosi tendencijos XVII-XVIII amžiuje. Acta Linguistica Lithuanica, 2017(76), 53-77.

Ragauskaite, A. (2018a). XVII a. kèdainiečių asmenvardžių darybos tendencijos. Baltu filologija, 27(1-2), 101-118. https://doi.org/10.22364/bf.27.04

Ragauskaite, A. (2018b). XVII a. kèdainiečių lietuviškos kilmès asmenvardžiai. Acta Linguistica Lithuanica, 2018(78), 53-75.

Ragauskaitè, A. (2018c). The patterns of recording the names of German residents in Kedainiai in the nineteenth century: Introductory remarks. Acta Baltico-Slavica, 42, 173-188. https://doi.org/10.11649/abs.2018.009 
Ragauskaitė, A. (2019). Joniškiečių vyrų asmenvardžių darybos tendencijos seniausioje Lietuvoje 1599-1621 m. Joniškio krikšto metrikų knygoje. Acta Linguistica Lithuanica, 2019(80), 177-194. https://doi.org/10.35321/all80-08

Safarewicz, J. (1950). Polskie imiona pochodzenia litewskiego. Język Polski, 30(3), 113-119.

Sinkevičiūtè, D. (2016). Lietuvių dvikamienių vardų trumpinių kilmės asmenvardžiai ir jų kamienų užrašymo ypatybès Vilniaus naujųjų miestiečių ir laiduotojų 1661-1795 metų sąraše. Archivum Lithuanicum, 18, 221-254.

Sinkevičiūtè, D., \& Račickaja, V. (2014). Lietuvių dvikamienių vardų kilmės asmenvardžiai ir jų kamienų užrašymo ypatybès Vilniaus naujųjų miestiečių ir laiduotojų 1661-1795 metų sąraše. Archivum Lithuanicum, 16, 295-322.

Šinkūnas, P. (1928). Kèdainiu miesto istorija. "Spindulio" B-vès spaustuvè.

Tworek, S. (1966). Z dziejów kalwinizmu w Wielkim Księstwie Litewskim w XVIII w. Annales Universitatis Mariae Curie-Skłodowska, 21(8), 193-202.

Tworek, S. (1969). Materiały do dziejów kalwinizmu w Wielkim Księstwie Litewskim w XVII wieku. Odrodzenie i Reformacja w Polsce, 14, 213-215.

Tyla, A. (1999). Decemviratas arba Tertio ordo communitatis Kèdainių savivaldoje. Lietuvos istorijos metraštis, 1999, 64-76.

Tyla, A. (2002). Lietuvos magdeburginiu miestu privilegijos ir aktai: Kédainiai. Lietuvos istorijos instituto leidykla.

Wolff, A. (1957). Projekt instrukcji wydawniczej dla pisanych źródeł historycznych do połowy XVI wieku. Studia Źródłoznawcze, 1, 155-181.

Zinkevičius, Z. (1977). Lietuvių antroponimika. Vilniaus lietuvių asmenvardžiai XVII a. pradžioje. Mokslas.

Zinkevičius, Z. (2008). Lietuvių asmenvardžiai. Lietuvių kalbos institutas.

Žirgulis, R. (2002a). Škotų bendruomenè Kèdainiuose 1630-1750 m. In R. Navardauskas Palaima (Ed.), Lietuvos muziejų rinkiniai (Vol. 1, pp. 23-27). Kėdainių krašto muziejus.

Žirgulis, R. (2002b). Three hundred years of multiculturalism in Kèdainiai. In G. Potašenko (Ed.), The peoples of the Grand Duchy of Lithuania (pp. 130-140). Aidai.

\title{
Language Contact Between Lithuanian and Polish in the Historical Anthroponymy of Kèdainiai Town of the Seventeenth and Eighteenth Centuries
}

\begin{abstract}
This article presents Lithuanian naming trends specific to residents of Kedainiai in the seventeenth and eighteenth centuries, underlining characteristic cases of Polonisation of their personal names and the most significant factors that affected the recording of anthroponyms in town books. Historical records from the seventeenth and eighteenth
\end{abstract}


centuries (24 Kèdainiai register books from 1623-1799) were used to extract 505 cases of names of Kedainiai residents. For comparison, the study also considers examples from the 1752-1799 register of christenings kept by St George's Church of Kèdainiai Parish. The sources under consideration mostly relied on the binary nomination model (using a name and a surname or a personal name that performed the function of the latter), where the first component was a Christian name written in Polish or Latin. In seventeenth-century records, surnames were Polonised: obvious cases of phonetic alterations were noted, some surnames had no endings, some Lithuanian patronymic and diminutive suffixes were replaced with Slavic suffixes, and Slavic patronymic suffixes -evič, -ovič were added to names without suffixes. However, the Slavicisation of anthroponyms particular to Kedainiai residents in the seventeenth century was not very intense due to extralinguistic and historical circumstances. In the Grand Duchy of Lithuania, the town of Kedainiai was a Reformist centre of Lithuanianness, and the Lithuanian language was used in the public life of the town. This element of Lithuanianness can also be noticed in the analysed historical sources. Anthroponyms were mostly Polonised in Kedainiai register books from the eighteenth century. Slavic patronymic suffixes -evič, -ovič were predominant in this period.

Keywords: Kèdainiai; 17th-18th centuries; Kèdainiai residents; surnames; Polonisation

\section{Litewsko-polskie kontakty językowe w historycznej antroponimii siedemnasto- i osiemnastowiecznych Kiejdan}

\section{Streszczenie}

Niniejszy artykuł omawia litewskie tendencje antroponimiczne charakterystyczne dla mieszkańców Kiejdan w XVII i XVIII wieku, podkreślając charakterystyczne przypadki polonizacji oraz najistotniejsze czynniki, które wpłynęły na zapis antroponimów w księgach miejskich. Z siedemnasto- i osiemnastowiecznych zapisów (24 księgi miejskie z lat 1623-1799) wyekstrahowano 505 przypadków nazwisk mieszkańców Kiejdan. Dla porównania, w opracowaniu uwzględniono również przykłady z księgi chrztów z lat 1752-1799, prowadzonej przez kościół parafialny św. Jerzego w Kiejdanach. W omawianych zapisach źródłowych stosowano głównie antroponimy o modelu dwuczłonowym (użycie imienia i nazwiska lub imienia, które pełniło funkcję nazwiska), gdzie pierwszym elementem było imię chrzestne zapisywane po polsku lub po łacinie. W zapisach siedemnastowiecznych nazwiska polonizowano: odnotowano oczywiste przypadki zmian fonetycznych, niektóre nazwiska nie miały końcówek, niektóre litewskie przyrostki patronimiczne i deminutywne zastępowano 
przyrostkami słowiańskimi, słowiańskie przyrostki patronimiczne -ewicz, -owicz dodawano do nazwisk, które nie miały przyrostków. Mimo że slawizacja antroponimów była charakterystyczna dla Kiejdan w XVII wieku, nie była jednak szczególnie intensywna ze względu na uwarunkowania pozajęzykowe i historyczne. Kiejdany były ośrodkiem reformacji i litewskości, który posługiwał się językiem litewskim w życiu publicznym miasta. Ten element litewskości można również dostrzec w analizowanych źródłach historycznych. W księgach kiejdańskich z XVIII wieku antroponimy występują przeważnie $\mathrm{w}$ formach spolszczonych. W tym okresie dominowały słowiańskie przyrostki patronimiczne -ewicz, -owicz.

Słowa kluczowe: Kiejdany; XVII-XVIII wiek; mieszkańcy Kiejdan; nazwiska; polonizacja

Dr Alma Ragauskaitė, Senior Researcher at the Research Centre of Baltic Languages and Proper Names, Institute of the Lithuanian Language. PhD thesis - 2002, Institute of the Lithuanian Language and Vytautas Magnus University; author of one book and over thirty scholarly and popular articles; co-author of the Dictionary of Lithuanian Place Names, she wrote texts for the second and third volumes. Her scholarly interests include historical and contemporary anthroponymy, historical and contemporary toponymy. She implements and leads research projects.

Bibliography (selected): XVI-XVIII a. kauniečiu asmenvardžiai [Personal names of the citizens of Kaunas in the 16th-18th centuries], Vilnius 2005; Tendencies in the evolution of hereditary surnames of townspeople in Lithuania from the sixteenth to eighteenth centuries, Zunamen/Surnames 3(1), Hamburg 2008, 29-37; Škotų pavardžių užrašymo tendencijos XVII-XVIII a. Kèdainių miesto istorijos šaltiniuose [Tendencies of recording Scottish surnames in the 17th-18th century historical sources of Kèdainiai], Acta Linguistica Lithuania 75, Vilnius 2016, 45-67; The patterns of recording the names of German residents in Kedainiai in the nineteenth century: Introductory remarks, Acta Baltico-Slavica 42, Warszawa (Warsaw) 2018, 173-188; Tendencies of formation of anthroponyms of rural residents in the oldest Lithuanian parish register of Joniškis dated 1599-1621, Onomástica Desde América Latina 2(3), Parana 2021, 2-29.

Correspondence: Alma Ragauskaite, Institute of the Lithuanian Language, Vilnius, e-mail: alma.ragauskaite@lki.lt 
Support of the work: This work was supported by core funding for statutory activities of the Institute of the Lithuanian Language.

Competing interests: No competing interests have been declared.

Publication History: Received: 2021-03-01; Accepted: 2021-06-10; Published: 2021$12-21$. 